
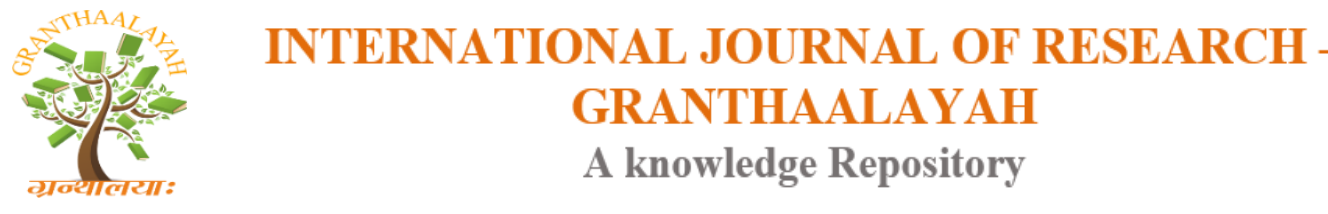

Social

\title{
THE IMPACT OF LIBERALIZATION OF ASEAN AIR TRANSPORTATION ON INDONESIAN AIRLINES
}

\author{
Oentoeng Wahjoe ${ }^{* 1}$, Dini Dewi Heniarti ${ }^{2}$, Anita Puspawati ${ }^{3}$ \\ ${ }^{* 1,2,3}$ Faculty of Law, Universitas Islam Bandung, Indonesia
}

\begin{abstract}
Liberalisation of air transportation practically is known as open sky policy. In the practice, the liberalisation of air transportation is divided into two group of services, i.e.: air transportation services, for passengers and goods (air service) which is categorized as hard rights and supporting services of the air transportation services (ancillary services) which is categorized as soft rights. The research in this paper focused in air transportation services for passengers and goods, consists of nine freedom of the air. The impact of the policy such as the Agreement regarding ASEAN open sky policy, is the readiness of Indonesian air transportation companies to compete with foreign air transportation companies. The government of Indonesia has to regulate the implementation of ASEAN Open Sky Policy to be projected in order to comply with national development, i.e. the function of air law in national development. The policy has been implemented by enact or amend the existing law as air law that regulate flight lines, the following provisions: To regulate flight line for foreign airlines to open flight lines in Indonesia region which may not or have not land and sea transportation. The regulation is intended to support mobility of humans, goods and services that may fulfil the needs of the people of Indonesia, which materially and spiritually and the development of the region. The regulation of flight lines of foreign air transportation for region of tourism, industrial and trade center. The regulation is intended to support the national economic development of Indonesia.
\end{abstract}

Keywords: Air Transport; Liberalization; Indonesian Airlines.

Cite This Article: Oentoeng Wahjoe, Dini Dewi Heniarti, and Anita Puspawati. (2019). "THE IMPACT OF LIBERALIZATION OF ASEAN AIR TRANSPORTATION ON INDONESIAN AIRLINES." International Journal of Research - Granthaalayah, 7(9), 332-341. https://doi.org/10.29121/granthaalayah.v7.i9.2019.616.

\section{Introduction}

The efforts of world community in the fight for world trade to build international institutions, that is embodied World Trade Organization (WTO ) on the January, 1st, 1995. The World Trade Organization (WTO) to take charge of the role of GATT in maintaining the system of international free trade. It is taken as treas on Uruguay Round. In these negotiations, yields 28 agreements which regulates trading in goods, services and the protection of intellectual property. The agreement on 
trade in services was born in December 1993, contained GATS (General Agreement on Trade in Services). Some provisions relating to the treaty for the accession of Uruguay Round are annexes of WTO.

The rules of World Trade Organization (GATS-WTO) to take charge of the role GATT in maintaining an open system of international free trade. It is taken as treas on Uruguay Round. In these negotiations yields 28 the agreement which regulates trading goods, trading in services and the protection of intellectual property [1]. Agreement on trade in services alone was born in December 1993 contained GATs (general agreement on trade in services). Some provisions relating to the treaty for the accession of Uruguay Round of WTO re-after is.

\section{Results and Discussions}

\subsection{Services According to GATS Provisions}

GATS is annex of the 1994 Marakesh agreement, especially Annex 1B, which basically means extending function of GATT in the field of services. The consent in this agreement, actually set GATS trade liberalization in the field of services to spur growth and development of world economy. The study of the GATS or General Agreement on Trade in Services, must consider three sorts of documents. The first is GATS agreement itself is the framework agreement consisting of 39 articles which are divided into six pieces [2]. In the three of the first part of this agreement containing one device, general conceptions, principles and provisions that raises the obligations with respect to set by all the act of a trading treaty services. Trade services, arranged in three parts of trade services itself arranged in three parts.

Part I, containing basic obligations with regard to the definition and scope of services. Part II, containing a provision with regard to common liabilities as MFN; tranparancy; provisions for participation increased from developing countries global trade in services; the domestic regulations set by merit; the obligations regarding conditions for recognition in services; the use of restraint in international transfers and payments there is found difficulty in terms of balance of payment and enactment exeption either spatially general.

Part III is the operative, containing of the provisions on market access and the national treatment. The provisions concerning about market access and treatment this national obligation, not grafted as general, but as specifics commitments to be loaded in the list of national commitment (national schedule). Part IV, laying the ground work for a progressive liberalization of trade negotiations on services through provisions services, including inside the withdrawal and modification of the list of commitments in national schedule commitment after three months.

Part V, includes provisions GATS, including the establishment of institutions the council on the trade in services and consultations with the provisions regarding the procedure of dispute settlement. Whereas part VI contain provisions of the end (the provision). In paragraph 2 of article 1 GATS, stipulates that means Trade in Services are conducted by means of the modes of supply:

- the services provided from one region contracting party to other contracting party, e.g services using media telecommunications (including transportation services-writer); 
- the services provided within the territory of one state to consumers from other contracting state e.g tourism services;

- the services provided by business entities presence within the territory of a state other countries for example through an opening foreign bank branches or representative offices;

- the services rendered by citizens participants within the territory of other contracting states e.g through merit consultan and accountant.

The implementing of trade in service has based on principles of an open trading system free and competitive as the management structure of the world economy in general guidelines of the GATT [3].

\subsection{Principles in GATS}

\section{The Most Favoured Nations Treatment-MFN}

This principle set out in article I GATT 1994 which requires all commitment made or signed in order GATT-who should be treated equally to all the members of the WTO (non continued discrimination) unreservedly. For example, a country not allowed to impose the tariffs to a different country than in other countries. The most favoured nations be poured back in article II that requires GATS the point is that the member states for an immediate and unconditional would not give distinct (no less favourable) to merit and suppliers from other countries, comparable to be given to the service of other countries. Exceptions to this principle can be granted with the requirement as stipulated in article 2 are about an exception. This principle also excluded for adjecent countries (nations) with the member states, especially for the services produced and consumed in the border areas [4].

\section{National Treatment}

The principle that a member states establishing that products imported into a country should be treated same as well as a domestic product. This principle sector sub-sector applied or expressed in schedule, commitment and subject to all conditions and qualifications that are included in it [5]. This article, commitment as cannot be interpreted to require a country to give compensation inherent due to competitive advantages. Both this principle in commerce as basic services arranged in annex ib which includes all services (except services sector that supplied services for the purposes of the government). Services rendered in connection with the government namely services rendered not commercially or in competition with one or more service provider.

\subsection{Exclusion of Air Traffic}

The exclusion of air traffic in free trade is cabotage, referring to an institution either in the sea and air transportation which is right ekslusif of a country. To that provision GATS own exclude air traffic rights and services that deals with the rights of the air traffic within civil aviation as stipulated in annex of air transport services. This applies only to annex services as repairs and maintenance and treatments (repair aircraft, sales and marketing of services, flight or setting in air carriers and computer system revarasi revaration system (computer). Dispute pertaining to air transport services in annex GATs (on air transport services is also an exclude of solving disputes about traffic rights) [6]. 
The problem that is not less important in this discussion is over re both about movement of natural persons as re on air transport services. This is an essential function re arranging forms of services, with a commitment to comply with the aim of all that is in the GATS. Thus, the international civil aviation particularly the air transport shall be adjusted with the provision of free trade in services as regulated in GATS. The air transport services within the framework of the international civil aviation is the issue of the freedom of the air [7]. The freedom of the air may be done by requiring through bilateral agreement between contracting states, who will perform the civil aviation in the framework of an international air transport.

\subsection{Cabotage in the Free Trade Era}

Such as described, the problem of cabotage, either in the air or sea transportation, is a problem that is very closely related right to the exclusive right of a country. In terms of international law governing trade in civil aviation (open sky), namely the Annex on air transport services also excludes traffic rights (right to air traffic) and services related to the implementation of air traffic rights (excludes traffic rights and all services directly related to their operation) [8]. This annex is only valid for services such as repair and maintenance aircraft, sales and marketing of the services flight, transporting or setting up in the air and computer reparation system.

The question of trade liberalization of air transport services is actually different from the problem of national sovereignty in the air space as stipulated in Article 1 of the Convention. Air transport services under the GATS is an such world trade problems, but the airspace is the medium of international civil aviation such as sovereignty [9]. So, the second problem is a different matter, and arranged in different international agreements. Keep in mind that "sovereignty" is a principle of international law, which is different from international law established by international agreement. Yet that is the basis of the Convention on international civil aviation regulation does not cover the trade liberalization efforts of air transport services with the principle of free trade, competitive and non-discriminatory [10].

As explained that the question of free trade in the field of air transport services are very relevant to the question of the Freedom of the Air (freedom flight) arranged by the annex of the Convention. It was certainly related to the board's questioning of cabotage is one of eight freedom of the air, namely the Eight freedom. As one of the Freedom of the Air, the board of cabotage would be used as a means "free market access" to air transport service by the Contracting parties in order to implement the GATS. As recognized by all Contracting Parties, that cabotage is a very sensitive issue and exempt from the provisions of GATS. The GATS is a multilateral regime, however, a body of the GATS push for the implementation of GATS market access in the development of air transport in particular cabotage services, can be done by taking into account the principle of fair competition and most-favored-nation (MFN) [11].

If it is associated with the provisions of the Convention, is also the issue of cabotage actually sovereignty in the form of the right to control the commercial rights in the field of air traffic (traffic right) in the region of the country (the Eight freedom) is often called "hard right". The actual traffic rights could be exchanged based on the principle of reciprocity, with through bilateral agreements (bilateral regimes). Bilateralism in realizing the principle of reciprocity is a reasonable thing to do in international relations, especially trade relations between countries, due to the current realities 
of the international community is still composed of independent states, sovereign and equal, and the coordination of international legal order [12]. The principle of bilateral (bilateral regimes) are also used in the GATS provisions are law making treaties. This is possible, because although GATS leads to liberalize trade in services by expanding access to markets throughout the world progressively, the approach remains through bilateral, plurateral, and then multilateral agreements stages.

The possibility of exchange of cabotage, because under Article 7 of the Convention specifies that the state can reject the airlines of the other participating countries to undertake air transport services between airports within the country. Thus of course the state can only allow foreign airline companies to perform services in the country's air transport, because it is not a ban, although cabotage rights is a form of state sovereignty in the field of air transport. As explained in the preceding discussion, that cabotage which is basically the Eights freedom of the Freedom of the Air.

Before the era of free trade proclaimed through GATS, international civil aviation under the Convention and its annex set the matter Freedom of the Air. The right to fly in the territory of other countries in the framework of international civil aviation, for activities to carry passengers, baggage and cargo, has a lot to do with how exchanged by the participating countries of the Convention through bilateral Agreements on Air Traffic through an inter-agency agreement with the government ( $\mathrm{G}$ to $\mathrm{G}$ ) as where the Two Freedoms Agreement or the Five Freedoms Agreement.

\subsection{Liberalization of Air Freight Services Practice in Some Countries}

As mentioned above that the development in the framework of GATS market access can be done by bilateral agreement, then of course access to the cabotage market can also be exchanged through such means or bilateral regimes. Exchange of cabotage is certainly not reduce the sovereignty of the country, as in this exchange there is the principle of reciprocity. Exchange of cabotage can be done by the state government with other countries, through bartering with the principle of mutual benefit [13].

Exchange of cabotage which is the freedom of the eight European countries that joined the European Union has been going on since January 1, 1993 embodiments of the European single market society full and launching the integrated air traffic market of the EEC. Exchange of cabotage is a form of liberalization of air transport services between the European Union countries. Liberalization of air transport services in the European Union spearheaded by KLM Royal Dutch Airlines, which at the time was ready to compete freely with competitors (airlines) from EU countries other.

The liberalization of air freight services started with through bilateral agreements (bilateral regimes) among the European Union countries amounted to 12 countries. From bilateral regimes later changed to be returned to its original purpose of the formation of the European Union is based on "the Treaty of Rome" in the form of multilateral regimes. Implementation of the liberalization of air transport services in the European Union began with the release of "the first liberation package" which launched the free competition in the field of air transport services accepted in 1993. 
Issued in November 1990 "the second package" in the form of fifth freedom. Operations throughout Europe, and later of the date of January 1, 1993 issued "the third package" which imposed a complete freedom to fly (freedom of flight/the air) ie fourth freedom, fifth freedom, sixth freedom, seven freedom, and eighth freedom to all destinations around the country who are members of the European Union, amounting to 12 countries. The liberalization of air transport will be carried out among all the EU countries with the United States. The possibility also sought through bilateral regimes between the EU member states with the United States. If the Drafts negotiating mandate was agreed that "free market access" between the European Union countries with the United States will soon be realized [14].

\subsection{Indonesian Air Law According to the Political Law of Cabotage}

Air Transport Policy Issues in Indonesia, of course, not far from other ASEAN countries. Indonesia Air Transport Policy carried by air transport agreement with the reciprocal Bilateral Air Transport Agreement with other countries. Bilateral Air Transport Agreement which has been done by the Government of Indonesia is to some of the freedom of flight, that is the first freedom, the second freedom, third freedom and the fifth freedom. Thus, the Indonesian air transport policy does not lead to a free market access on Air Services, even expressly based on Law of Flight No.1/2009 prohibits cabotage in Indonesian airspace sovereignty [15].

The issue of banning cabotage by Law no. 1/2009 on Aviation is a reflection of the political air Indonesian law against free trade in the field of air transport services in Indonesia. The law of a country's political problems in the science of law is a question of law functions in this model of development adopted in Indonesian law. Function of law and the role of law for the establishment of legal development in Indonesia is not only directed at the function of the law as a tool to maintain order and the rule of law in society, but also must be to the legal function as a means to bring changes in the society especially in the face of trade free. For legal function has been developed by Roscoe Pound with the term "social engineering" and in Indonesia developed by Kusumaatmadja [16] with the term means "community development".

As the dictum weighing of the law can be seen that the purpose and motivation formation of air law is to achieve national development goals as Pancasila. Law. 1/2009 states that the transport has an important and strategic position in the national development of environmentally sound and this should be reflected on the need for mobility across sectors and regions. Transportation is a very important tool and strategic in expediting the economy, strengthening the unity and integrity, affecting all aspects of the life of the nation and strengthen the relationship between the state and the nation.

The importance of transport arrangements using air craft as well, due to the fact the increasing need for transportation services for the mobility of people and goods to and from all corners of the country, and even from abroad. Transportation also plays a role as supporting, driving, and driving force for regional growth potential, although not developed as it should be, for improved and equitable development and results [17].

Realizing the role of transport, the operation of flights should be arranged in a single integrated national transportation system and is able to realize the provision of transport services are balanced 
with the needs and availability of transportation services that can ensure the safety, security, fast, smooth, orderly, organized, comfortable and fruitfully with reasonable prices. Under this legislation is also expected to have the flight characteristics and its own advantages, and attention by developing capital-intensive nature so as to enhance a wider range of both domestic and abroad.

Given the important and strategic role that account for people's life, then the cost is controlled by the state developed by the Government. Implementation of flight needs to be held on an ongoing basis and continue to be improved so that a wider coverage of and service to the community with the greatest attention to the public interest and the ability of communities, environmental sustainability, coordination between central and local authorities as well as between institutions, sectors, and inter-related elements and defenses and state security, as well as in order to create a reliable national transportation system and integrated.

Article 4 of Law no. 1/1999, that as a sovereign state, the Republic of Indonesia has a full and complete sovereignty in the airspace of the Republic of Indonesia, in accordance with the provisions of the 1944 Chicago Convention on International Civil Aviation and International Law of the Sea Convention of 1982 which was ratified by Law No. 17 Year 1985 on Ratification United Nations Convention on the law of the Sea.

Provisions in the article only confirms the authority and responsibility of the Republic of Indonesia to regulate the use of airspace which is part of Indonesia, while the sovereignty over the territory of the Republic of Indonesia as a whole continue to apply the provisions of legislation in the field of national defense. Article 5 The airspace in the form of air space above the land and waters of the Republic of Indonesia is a national treasure that must be used for the greater interest of the people, nation, and state. Rights to natural resources such as air space as a medium of commercial air transportation is basically a manifestation of Indonesia's economic sovereignty, both internal and external.

In addition to air space as a national treasure that embodies the sovereignty of the Indonesian economy, both internal and external, under Article 7 (1) states have the right to control the organization of flight manifestations including aspects of regulation, control, and surveillance. Scrutiny of the results of the dictum and torso Law. 1/2009, then the function of the law of the law has led to the development of national development efforts, especially water in the Indonesian legal system in general in this case the national aviation system. For the construction of the functions of the national air transportation system, and even the International Air transportation that use Indonesian air space, according to the opinion of the writer is not fully lead to the empowerment of people in the world of air transport, both as a community organizer and public modes of air transport air transport service users, as well as the community other potentially vast incur losses (potential victim) of the air transport activities in particular and general aviation activities.

Neglect of the role of the Indonesian air law to community development efforts in the field of national aviation in general and in particular the development of air transport, not only because of the role of regulator or policy makers in the field of aviation and air transport, but is also involved in organizing aviation and air transport itself (although just as the owners of capital). Provision of piling on the role as organizer of the state government, would be potentially the abuses of power 
and leads to corruption. Some drawbacks of Law No.1 / 1999 mentioned above, the concept of the function of law as a means of community development, both initiated by Rooscopon and Mochtar Kusumaatmadja not achieved. Law 1/1999 only build systems that airlines only provide a portion of the authority that many of the state officials, both central and local levels.

In general, the National Law Commission in the results of his research found many inaccuracies in the reform and development of national laws Indonesia (PRH/ Legal Reform Program), for example, prioritize the state institutions on legal drafting, while advocacy groups prioritize people's rights. By $\mathrm{PRH}$, prioritize state institutions in the financial sector, while the community groups to prioritize the judicial sector.

Based on the above facts it is in general (not just the law of the air) legal development in Indonesia, is understood as the creation of new laws. It is the dominance of the legal theory developed by Kusumaatmadja [16] in line with the flow of positivism, utilitarian, which tend to ignore justice, because it tends to be on the development of the theory of society (be stuck on) the material (welfare) alone, not to spiritual (justice). That it is because, in addition to the legal theory of culture born from the womb of a liberal society, the success rate is also due to the determination of the legal theory tends to be measured in terms of quantitative (as more scalable), not using qualitative measures.

Actually, speaking the law, not just talking the laws, regulations or other written laws, but the law has so many aspects and also consists of many components or other elements. The question of determining aspects or where the most important element, according to Borenstein [18] depending on legal philosophy embraced by the legal system of the country concerned. In Indonesia, the emphasis is on the formulation of a series of the rules of laws, regulations and rules (processes and procedures), whereas in America the emphasis is instead placed on the role of the courts as a legal institution, while in the Netherlands the pressure on the behavior required by the deviation government sanctioned.

Doctrine of legal relationship with the community - including the role of law in social change - by Bagir Manan has long been recognized and studied Indonesian legal experts. But only in the seventies that the teachings more openly discussed and attributed to renewal policies (development) law, even national development, as later published in the Guidelines, Five-Year Plan, and Annual Program (Budget). Besides discussed in various discussions (scientific or common), the new orientation of the legal relationship with the community and development, also the themes of writing in the legal field and the addition of the subject in law schools.

Furthermore what is said by Button [8] who say that the law means to understand human understanding, which is the point of view of understanding the laws that lead to "the man behind the gun", which proves that it is precisely the human factor plays a more dominant of the problem structure. In line with the opinion of Borenstein [7] stated that the main component of the legal subsystem of the social system is the man that is in it. The role is very dominant man, both from the design of a rule, the formulation stage to stage and so on so that law enforcement is an infinite cycle. The problem of development (system) in Indonesian law, which would have an impact on the development of air law in Indonesia, because the air is a sub-law legal systems of Indonesian law. 


\section{Conclusions}

From the brief description above, a number of conclusions and recommendations to examine the issue of cabotage institutions in international air transport as a means of realizing a free trade international air transport services from the perspective of air law (international). That cabotage under the 1944 Chicago Convention is a very sensitive issue because it involves the sovereignty of a country and is the exclusive right of the state to the national airline in the country or aircraft registered in the country. However, the law governing the air Freedom of the Air which allows cabotage institutions can be exchanged through bilateral agreements. Cabotage in the air Law as the air services Annex on Air Transport Services under GATS excluded (excludes traffic rights and all services directly related to their operation), but in practice development is not as in GATS provisions. Some countries practice primarily in the European Economic Community (EEC) liberalization of trade in services including air traffic. Thus cabotage, which is one form of free trade access (free market access) in the field of air transport services in accordance with the intent and spirit GATS. Cabotage (which is the eighth freedom) is actually a commercial rights that can be exchanged, as well as other Fredom of flight. Exchange is done through bilateral cabotage regimes, although GATS is a multilateral regimes. Cabotage is basically a service that can be traded as services are regulated by other. The practice of free trade in air transport services as the embodiment of cabotage, has been practiced in Europe in creating the European Economic Community.

Indonesian Air Law functions as intended yet as means legal concept of national development, both the concept of Rooscopone, and Kusumaatmaja. Law Politics of Indonesian Air Law, particularly in the areas of air transport, does not empower the providers of air transport (Air Lines), but the dominant role of the government, as well as regulators and policy makers in the field of aviation and air transport, air law has not shown Indonesian politics which serve the national interests of the destination countries of Indonesia, though Law No.1/1999 is quite protective of air freight services industry ordinate domestically, because the law prohibits cabotage. Indonesian Air Law functions in free trade in international air freight services, does not have a clear direction, because the Indonesian legal system has not been able to build a legal system in accordance with the purpose of Indonesian air space.

Need to build a national air law which can serve as a means of national development (both material and spiritual), and are able to follow the development of international trade (services) International, which supports the economic development of the World: a) In connection with the open skies policy, the government of Indonesa can do air agreement with another countries, in the form of freedom of the air that is based on national interests and welfare of the Indonesian people; b) Air agreement made by Indonesia, had through bilateral regime, taking into account national interests and security in the form of the economic potential of the Indonesian air space, which can be used as commodity trading, the development of the air transport industry, both domestically and internationally of the national Indonesian airline devoted to the interests of economic development through the means of the air transportation.

\section{References}

[1] Brueckner, J.K. and Whelen W.T. (2000), The price effect of international airline alliances, Journal of Law and Economics, 43, 503-545. 
[2] Clougherty, J.A. and Zhang, A. (2009), Domestic Rivalry and Export Performance: Theory and Evidence from International Airline Markets, Canadian Journal of Economics, 42(2), pp 440-468.

[3] Hummels, D. (2006), Global Trends in Trade and Transportation, ECMT-OECD Paper presented in the 17th International Symposium on Theory and Practice in Transport Economics and Policy, Berlin, 25-27 October 2006.

[4] General Accountability Office (GAO, 2008), Airline Industry: Potential Mergers and Acquisitions Driven by Financial and Competitive Pressures, GAO-08-845 July 31, 2008.

[5] Harrigan, J. (2005), Airplanes and Comparative Advantage, NBER Working Paper No. 11688.

[6] Clougherty, J.A. (2002), US Domestic Airline Mergers: The Neglected International Determinants, International Journal of Industrial Organization, 20, 557-576.

[7] Borenstein, S. and Rose, N.L., (2007), How Airline Markets Work...or do they? Regulatory Reform in the Airline Industry, NBER Working Paper 13452.

[8] Button, K. (1998), Opening U.S. Skies to Global Airline Competition, Trade Policy Analysis, Trade Policy Analysis, Nov.24.

[9] Piermartini, R. and Rousova, L. (2008), Liberalization of Air Transport Services and Passenger Traffic, World Trade Organization - Economic Research and Statistics Division, Staff Working Paper ERSD-2008-06.

[10] Zhang, A., Hanaoka, S., Inamura, H. and Ishikura, T. (2009), Low Cost Carriers in Asia: Deregulation, Regional Liberalization and Secondary Airports, Research in Transport Economics, Vol. 17, forthcoming.

[11] Lee, D., and Prado, M. J. (2005), The Impact of Passenger Mix on Reported "Hub Premiums" in the U.S. Airline Industry, Southern Economic Journal, 72, pp.372-396.

[12] Oum, T.H. and Yu, C. (1998). Winning Airlines: Productivity and Cost Competitiveness of the World's Major Airlines, Kluwer Academic Press, New York, London; 1998), 240 pages. http://www.wkap.nl/prod/b/0-7923-8010-X.

[13] Boeing (Boeing Commercial Aircrafts) (2008), Review of Boeing Commercial Airplanes Longterm Airplane Market Forecast Methodology and Airlines's Underlying Requirement for Economic Profits, public distribution version.

[14] Richards, K., (1996), The Effect of Southwest Airlines on US Airline Markets. Research in Transportation Economics, 4, pp.33-47.

[15] US DOT, (1993), The Airline Deregulation Evolution Continues: The Southwest Effect, Office of Aviation Analysis, US Department of Transportation.

[16] Kusumaatmadja, M. "WTO Agreement Regarding International Trade in Services (GATS) Viewed from the Perspective of Developing Countries", paper in International Commerce Upgrading Activities Law, Faculty of Law, Padjadjaran 28, July- August 8, 1997.

[17] Irwin, M. D. and Kasarda, J.D. (1991), Air Passenger Linkages and Employment Growth among U.S. Metropolitan Areas, American Sociological Review 56(4), 524-537.

[18] Borenstein, S., (1989), Hubs and High Fares: Dominance and Market Power in the U.S. Airline Industry, RAND Journal of Economics 20, 344-365.

\footnotetext{
*Corresponding author.

E-mail address: oentoengwahjoe.unisba@gmail.com
} 